\title{
Stabilization of Boumkaye's Drink for an Accessibility in the Markets
}

\author{
Oumar Ibn Khatab Cisse, (PhD student) \\ Nicolas Cyrille Ayessou, (Lecturer) \\ Bou Ndiaye, (PhD student) \\ Mady Cisse, (Professor) \\ Mama Sakho, (Lecturer) \\ Codou Mar Diop, (Professor)
}

Ecole Supérieure Polytechnique, Cheikh Anta Diop University, Dakar, Sénégal, Centre d'Etudes sur la Sécurité Alimentaire et les Molécules Fonctionnelles (CESAM), Dakar, Sénégal

Doi: 10.19044/esj.2018.v14n36p82 URL:http://dx.doi.org/10.19044/esj.2018.v14n36p82

\begin{abstract}
Boumkaye is a fermented drink made from millet, and prepared according to a traditional process from Casamance's region in Senegal. Still consumed for its anthelmintic properties, Boumkaye is obtained after maturation marked by two stages of fermentation (lactic and alcoholic). The main limits of this drink are the spontaneous nature of the fermentation and its instability. The objectives of this study is to stabilize this drink after fermentation step. For this purpose, an autoclave heat treatment at $120^{\circ} \mathrm{C} / 15$ minutes scale has been proposed. Two types of sterilized Boumkaye (crude and fermented) were kept at two temperatures $\left(4\right.$ and $25^{\circ} \mathrm{C}$ ) for one year follow-up. The sterilization tests on crude Boumkaye and fermented Boumkaye provided excellent microbiological and nutritional quality. No germ was detected during the entire storage period. In addition, Boumkaye beverages can be stored at $25^{\circ} \mathrm{C}$ (room temperature) for a minimum of one year while preserving all its organoleptic and therapeutic properties. This is a considerable asset for future industrial exploitation.
\end{abstract}

Keywords: Traditional drinks, Fermentation, Stabilization, Boumkaye

\section{Introduction}

Africa has real potential in terms of fermented cereal drinks. There is a great diversity of these local beers both in the cereals used (millet, maize, sorghum, rice) (Quin, 1959, Monjerezi et al., 2011) and in manufacturing 
processes (Kayodé et al., 2005, Maoura et al., 2005, Dicko et al., 2006, Lyumugabe et al., 2012). In Senegal, a fermented millet drink called Boumkaye is prepared by incorporating aqueous extracts of a medicinal plant, Abrus pulchellus. Boumkaye is known for its antihelminthic properties (Cisse et al., 2018).

Major limitations of African conventional beers are at the fermentation stage and stabilization processes that can guarantee sanitary quality. Indeed, the must is inoculated with a traditional starter and the fermentation time varies between 10 and 24 hours at room temperature (Kayodé et al., 2005, Lyumugabe et al., 2010). During storage, sorghumbased beers are consumed while still in fermentation (Mwesigye and Okurut, 1995). In the case of Boumkaye, a maturation stage characterized by a double fermentation (lactic and alcoholic), without addition of leaven, has been established (Cisse et al., 2018).

Thus, a stabilization of Boumkaye drink by autoclave heat treatment will be proposed to ensure its hygienic and sanitary quality; while preserving at best its nutritional and therapeutic characteristics.

\section{Material and methods}

\section{Production of Boumkaye drink}

Boumkaye was prepared in the laboratory according to the manufacturing chart prepared by Cisse et al., (2018). This process comprises three major and distinct parts: the production of an aqueous extract by maceration of the vines of Abrus pulchellus; the preparation of the millet porridge and a final fermentation and maturation phase.

Samples consisted of two types of Boumkaye. A crude Boumkaye that is not fermented; and a fermented Boumkaye, obtained after a maturation stage of two months. The drinks were packaged in $300 \mathrm{ml}$ jars (Figure 1). Analyses of each were performed in triplicate.

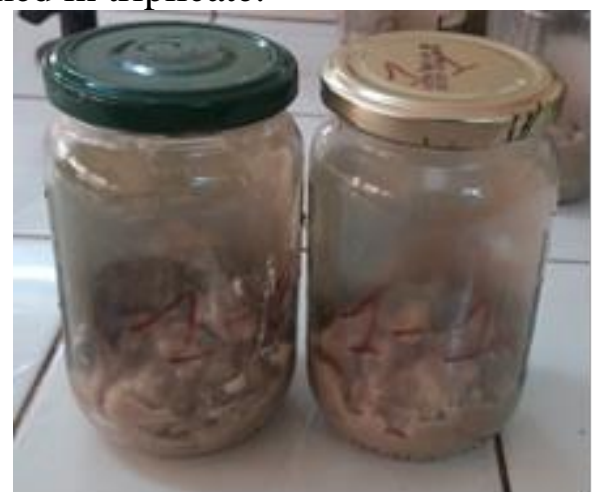

Figure 1. Millet-based beverages: (a) crude Boumkaye; b) fermented Boumkaye 


\section{Autoclave heat treatment}

Autoclave heat treatment was intended to eliminate all germs that could develop in Boumkaye. The sterilization was carried out using a laboratory autoclave of the type Lequeux (calculation pressure $2.5 \mathrm{bar}$, internal volume 270 liters, temperature $139^{\circ} \mathrm{C}$, year 1994) at the scale of $120^{\circ} \mathrm{C} / 15$ minutes at the pressure of 1 bar.

\section{Physicochemical methods}

$\mathrm{pH}$, titratable acidity, dry matter, reducing and total sugars, and ethanol content were evaluated according to standard AFNOR methods (AFNOR, 1982). The total polyphenols were evaluated by spectrophotometric test with Folin-Ciocalteu reagent in a basic medium at $760 \mathrm{~nm}$. The concentration of polyphenols is expressed in gallic acid equivalent (Georgé et al., 2005). The color indices (browning index and yellow index) were determined by the L*a*b system (AFNOR, 2011) using a laboratory colorimeter (Konika Minolta, CR C5).

\section{Microbiological methods}

Microbiological flora analyzed was related to the different fermentation reactions of Boumkaye beverage and the efficacy of sterilization. Germs were counted according to French standards (AFNOR, 2013).

\section{Statistical analyses}

The variance analysis tests (ANOVA) were performed with the STATISTICA 7.1 software. Statistical differences with a probability value less than 0.05 are considered significant.

\section{Study of the stability of sterilized beverages}

Millet-based beverages (crude Boumkaye and fermented Boumkaye) were sterilized and stored at two temperatures $\left(4\right.$ and $\left.25^{\circ} \mathrm{C}\right)$ for a 12 -month follow-up. The idea was to study the stability of the samples according to a monthly evaluation of physico-chemical and biochemical parameters $(\mathrm{pH}$, acidity, ethanol, color); and microbiological ones (total flora, lactic acid bacteria, yeasts and moulds).

\section{Results}

\section{Physico-chemical characteristics of Boumkaye beverages}

The initial characterization focused on millet-based beverages in order to define the impact of heat treatment on nutritional and organoleptic quality (Table 1).

Sterilization had no significant impact on physico-chemical and biochemical parameters of the crude Boumkaye excepted yellow and browning 
indices. For the fermented one any impact was notified for ashes, dry matter and browning index. Differences were especially noted in terms of polyphenols (251 mg/100g for unsterilized, to $326 \mathrm{mg} / 100 \mathrm{~g}$ for sterilized) and color indices which increase significantly in fermented Boumkaye. Other value were increased after sterilization of fermented Boumkaye, such us $\mathrm{pH}$ and titratable acidity.

Table 1. Characteristics of crude Boumkaye and fermented Boumkaye before and after sterilization

\begin{tabular}{lcccc}
\hline & \multicolumn{2}{c}{ Crude Boumkaye } & \multicolumn{2}{c}{ Fermented Boumkaye } \\
Analyzes & unsterilized & sterilized & unsterilized $^{\text {sterilized }}$ \\
\hline pH & $6.31 \pm 0.01^{\mathbf{a}}$ & $6.31 \pm 0.01^{\mathbf{a}}$ & $3.52 \pm 0.02^{\mathbf{b}}$ & $3.63 \pm 0.04^{\mathbf{c}}$ \\
\hline Dry matter (g/100g) & $10.41 \pm 0.24^{\mathbf{a}}$ & $10.64 \pm 0.52^{\mathbf{a}}$ & $15.44 \pm 0.51^{\mathbf{b}}$ & $14.94 \pm 0.10^{\mathbf{b}}$ \\
\hline Titratable acidity (mEq/100g) & $1.24 \pm 0.00^{\mathbf{a}}$ & $1.09 \pm 0.12^{\mathbf{a}}$ & $8.94 \pm 0.00^{\mathbf{b}}$ & $7.97 \pm 0.24^{\mathbf{c}}$ \\
\hline Ash $(\mathbf{g} / \mathbf{1 0 0 g )}$ & $0.29 \pm 0.11^{\mathbf{a}}$ & $0.14 \pm 0.01^{\mathbf{a}}$ & $0.24 \pm 0.03^{\mathbf{a}}$ & $0.24 \pm 0.03^{\mathbf{a}}$ \\
\hline Total sugars (g/100g) & $0.33 \pm 0.03^{\mathbf{a}}$ & $0.41 \pm 0.01^{\mathbf{a}}$ & $0.14 \pm 0.00^{\mathbf{b}}$ & $0.16 \pm 0.00^{\mathbf{c}}$ \\
\hline Reducing sugars (g/100g) & $0.30 \pm 0.01^{\mathbf{a}}$ & $0.37 \pm 0.01^{\mathbf{a}}$ & $0.12 \pm 0.02^{\mathbf{b}}$ & $0.13 \pm 0.02^{\mathbf{c}}$ \\
\hline Polyphenols (mg gallic acid/100g) & $82.95 \pm 7.54^{\mathbf{a}}$ & $86.79 \pm 8.69^{\mathbf{a}}$ & $251.61 \pm 5.87^{\mathbf{b}}$ & $326.01 \pm 3.17^{\mathbf{c}}$ \\
\hline Ethanol (g/100g) & - & - & $3.04 \pm 0.07^{\mathbf{a}}$ & $3.59 \pm 0.17^{\mathbf{b}}$ \\
\hline Yellow index & $31.71 \pm 0.17^{\mathbf{a}}$ & $36.14 \pm 0.02^{\mathbf{b}}$ & $42.35 \pm 0.04^{\mathbf{c}}$ & $41.69 \pm 0.00^{\mathbf{d}}$ \\
\hline Browning index & $31.46 \pm 0.25^{\mathbf{a}}$ & $39.08 \pm 0.00^{\mathbf{b}}$ & $46.36 \pm 0.07^{\mathbf{c}}$ & $46.74 \pm 0.00^{\mathbf{c}}$ \\
\hline
\end{tabular}

\section{Efficacy of heat treatment}

The efficacy of the heat treatment is evaluated by the microbiological quality of the product after autoclaving. Different germs were sought and the results obtained are recorded in Table 2.

Table 2. Microbiological evaluation of Boumkaye beverages before and after sterilization in $\mathrm{CFU} / \mathrm{g}$

\begin{tabular}{lcccc}
\hline & \multicolumn{2}{c}{ Crude Boumkaye } & \multicolumn{2}{c}{ Fermented Boumkaye } \\
Germs & Unsterilized & sterilized & Unsterilized & sterilized \\
\hline Total flora & 40000 & $<10$ & $360.10^{6}$ & $<10$ \\
\hline Lactobacilli & 3300 & $<10$ & $6.10^{6}$ & $<10$ \\
\hline Moulds & $<10$ & $<10$ & $<10$ & $<10$ \\
\hline Yeasts & 20000 & $<10$ & $19.10^{6}$ & $<10$ \\
\hline
\end{tabular}

Microbiological characterization shows a preponderance of lactobacilli and yeasts in unsterilized beverages at the expense of moulds. None germs was found after heat treatment. This proves indeed, the effectiveness of the method of stabilization with the autoclave.

\section{Study of the stability of sterilized beverages}

Stability study was designed to define the optimal temperature/duration conditions for the preservation of millet-based beverages. This results in a stability of crude and fermented Boumkaye throughout the duration of the monitoring, and regardless of the temperature for both physicochemical and microbiological parameters. Indeed, there were 
no significant differences between the results obtained during the aging study. The temperature $4^{\circ} \mathrm{C}$ has the same levels of preservation as the temperature $25^{\circ} \mathrm{C}$ (Figure 2, 3, 4, 5 and 6). Crude and fermented Boumkaye were exempted from germs during the stability study.
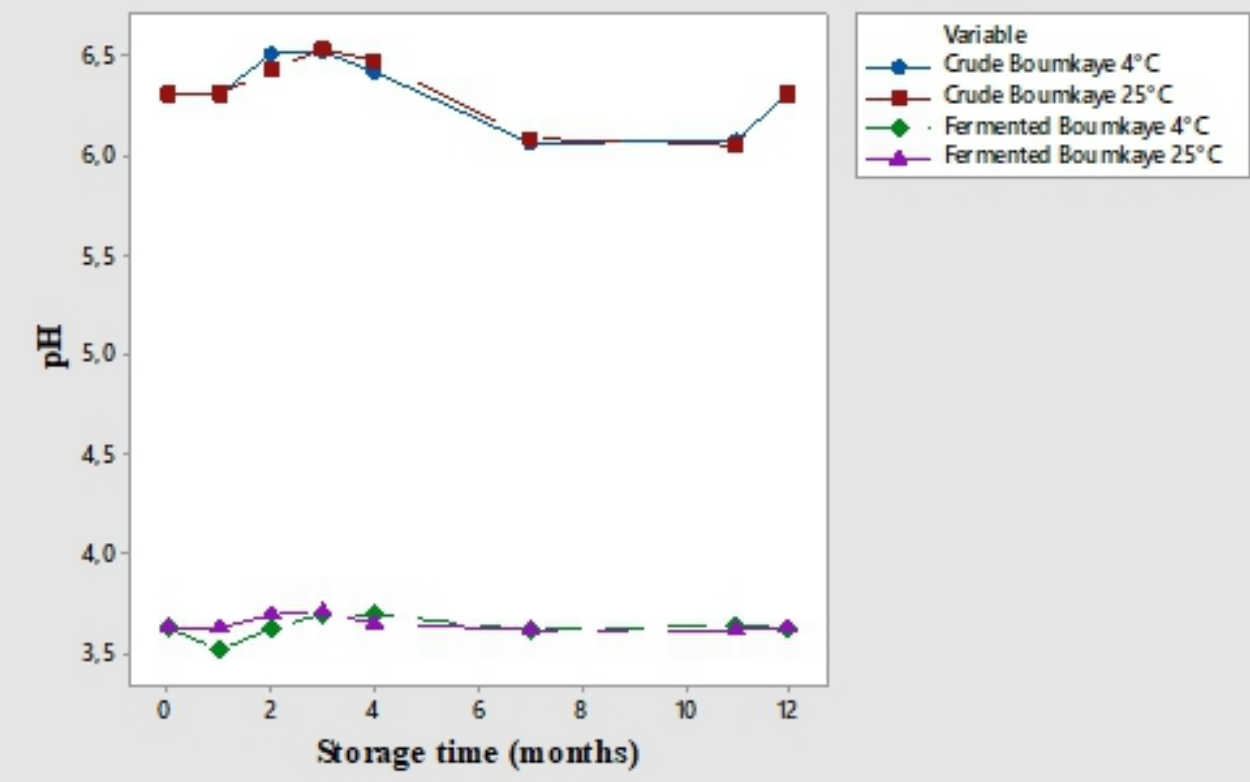

Figure 1. Evolution of the $\mathrm{pH}$ according to the storage period of Boumkaye

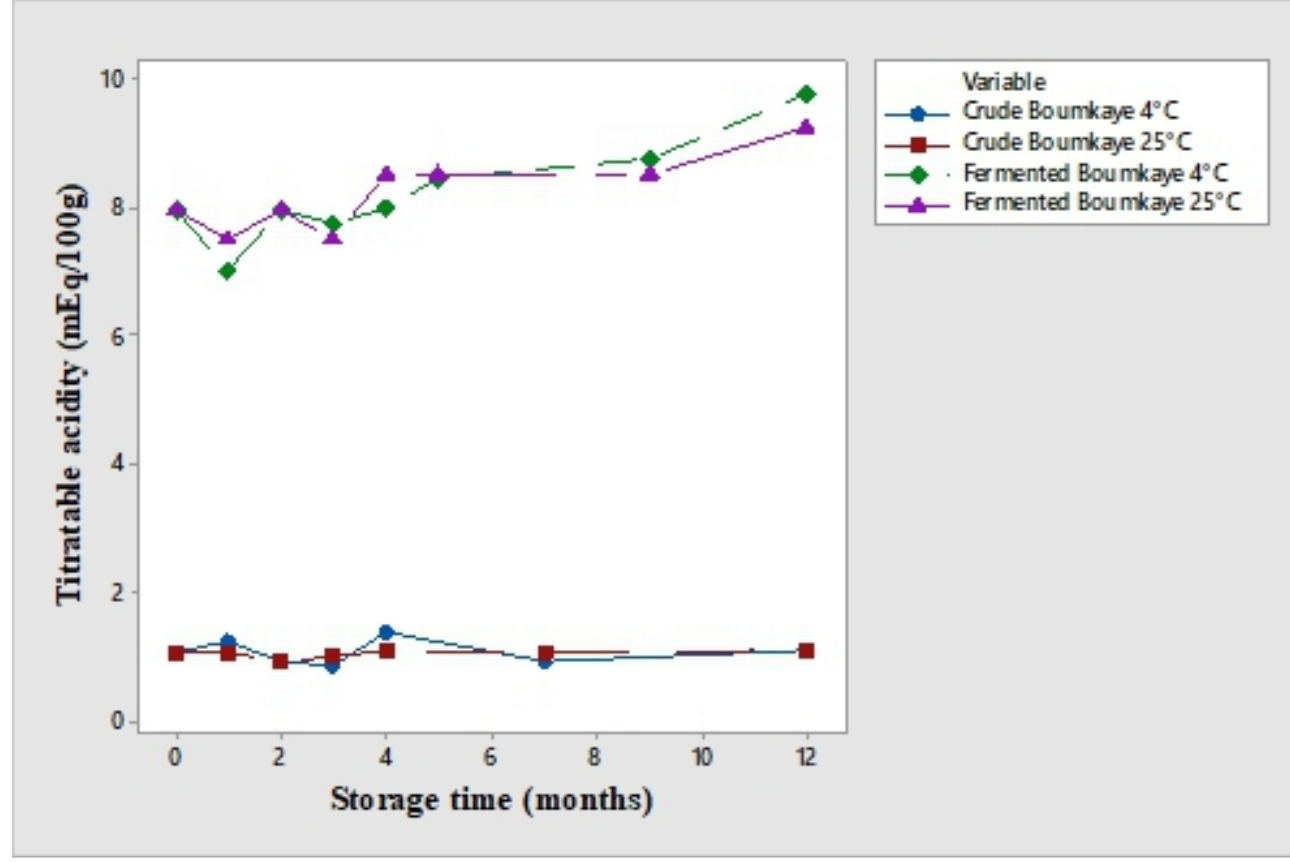

Figure 2. Evolution of the titratable acidity according to the storage period of Boumkaye 

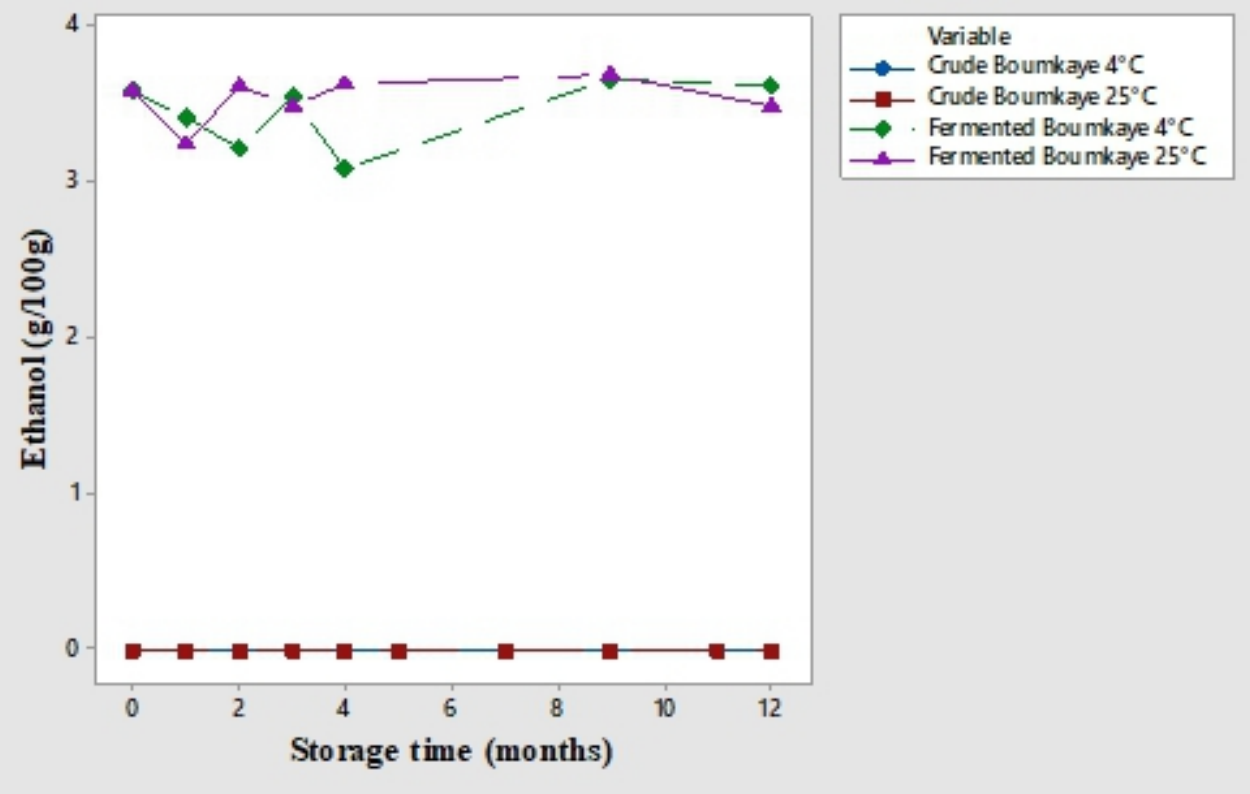

Figure 3. Evolution of the ethanol content according to the storage period of Boumkaye
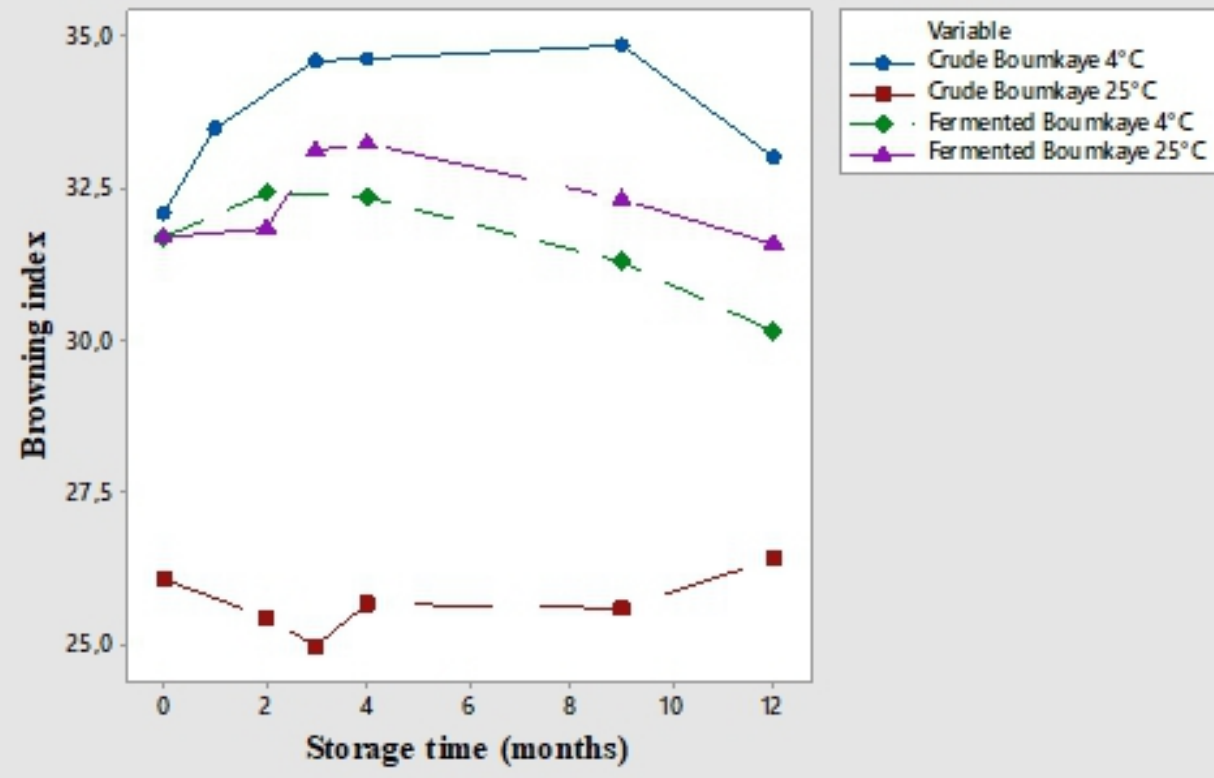

Figure 4. Evolution of the browning index according to the storage period of Boumkaye 


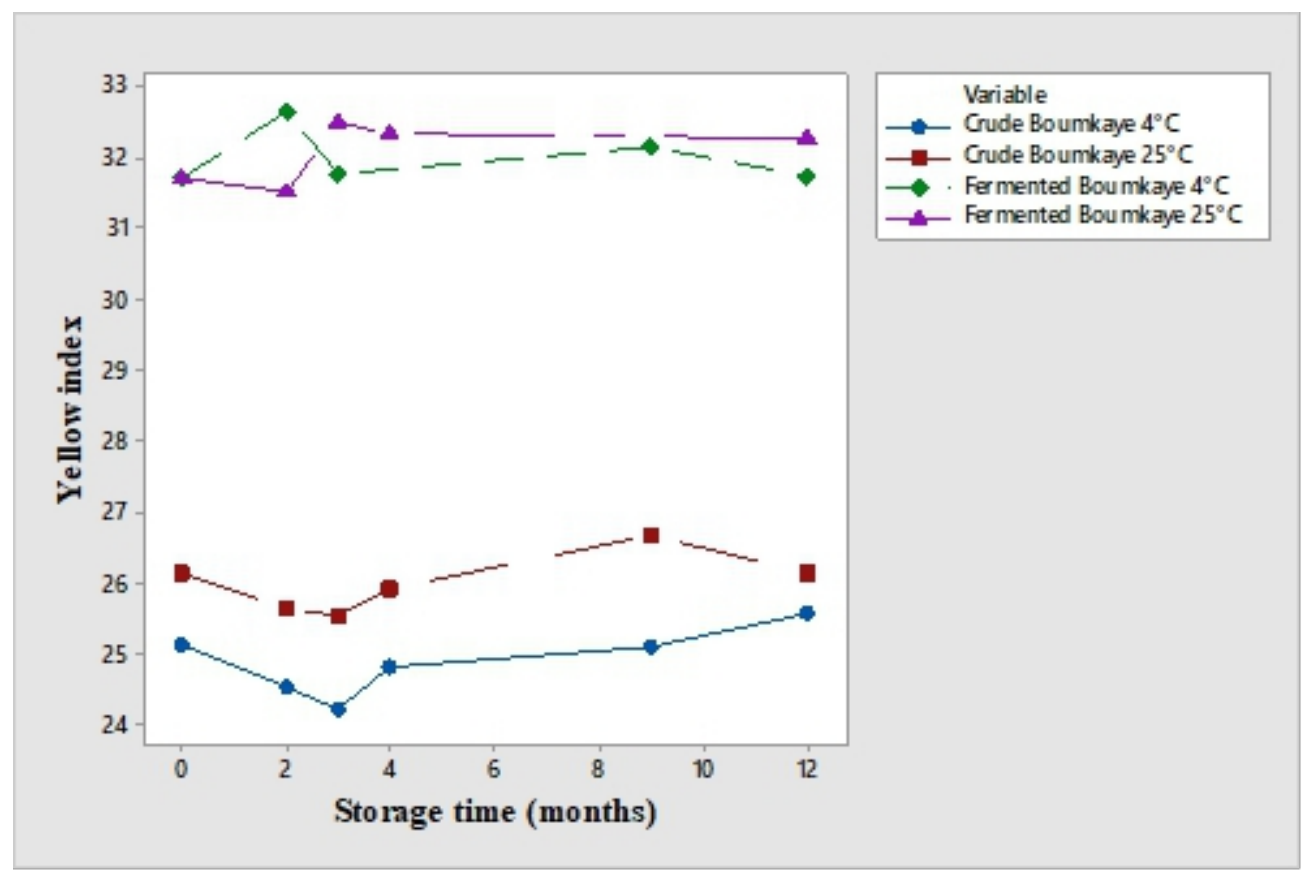

Figure 5. Evolution of the yellow index according to the storage period of Boumkaye

\section{Discussion}

The characteristics of the autoclaved Boumkaye beverages reflect the effectiveness of the sterilization which certainly must ensure a sanitary quality but while preserving the nutritional properties. In fact, the heat treatments lead essentially to physicochemical and biochemical changes that are more or less significant depending on the parameter considered. The differences noted between crude and fermented beverages are related to maturation in fermented Boumkaye. A maturation stage marked by a double fermentation (lactic and alcoholic) was detected, responsible for its high acidity and alcohol content (Cisse et al., 2018). Crude Boumkaye is considered as an intermediate product but may contain the same therapeutic properties (antihelminthic, antioxidant) as fermented Boumkaye. Crude Boumkaye drink is non-alcoholic which is an asset against cultural barriers.

In addition, from its primary use as an alcoholic beverage, fermented Boumkaye has more nutritional properties because of its much higher polyphenol content. Previous cereal research has indicated that a significant portion of the phenolic compounds is present in conjugated, soluble or bound form, insoluble. The heat treatment induces the hydrolysis of the conjugated phenolic compounds, resulting in the release of the free phenolic acids and thus increases the amount of bio-available phenolic compounds (Dewanto et al., 2002, Randhir et al., 2008, Ranilla et al., 2009). Chromatic indices noted and correlated with the yellow color, would significantly increase its sensory 
acceptance. Hop industrial beers offer a wide range of colors from pale gold to black. Color is much more than a classification criterion but of quality in terms of aromas and taste.

Most traditional African beers pose many health risks due to the spontaneous nature of fermentation (Kayodé et al., 2005, Lyumugabe et al., 2010). The musts are mostly inoculated with a traditional leaven (Maoura et al., 2005, Kayodé et al., 2005, Hounhouigan and Nout, 2007, Lyumugabe et al., 2010). The resulting beer has a dubious health quality due to the lack of control of the present germs. The manufacture of the drink Boumkaye has the particularity of incorporating a medicinal species Abrus pulchellus, which has positive effects on the stability and selection of Boumkaye flora (Cisse et al., 2018).

African autochthonous beers are characterized by infection and proliferation of yeasts and multilevel bacteria (F. Lyumugabe et al., 2012). These undesirable microorganisms (Acetobacter) produce acetic acid, volatile aromas, fruity scents and dandruff that make the taste, odor and texture unacceptable to consumers (Walt, 1956). Also, there are no differentiated stabilization methods for these local beers resulting in continued fermentation to consumption (Mwesigye and Okurut, 1995). In the case of the sorghumbased Tchapalo, an alcoholic fermentation takes place, accompanied by a natural lactic fermentation. The beers thus obtained can only be kept cool in order to reduce microbial growth (Dahouenon-Ahoussi et al., 2012). The autoclaved Boumkaye is free of germs until the end of monitoring and the drink can be stored at $25^{\circ} \mathrm{C}$ (room temperature) for at least 1 year. This is a considerable advantage for future industrial exploitation, especially since Pilstype industrial beers must be kept refrigerated $\left(4^{\circ} \mathrm{C}\right)$ for a maximum of 6 months.

\section{Conclusion}

Results show an effectiveness of heat treatment $\left(120^{\circ} \mathrm{C} / 15 \mathrm{mn}\right)$ which has preserved all the nutritional and therapeutic properties of Boumkaye. Also, no germ was detected during the follow-up. The stability study showed that crude Boumkaye (unfermented) and alcoholic fermented Boumkaye can be stored at $25^{\circ} \mathrm{C}$ for at least one year.

\section{References:}

1. Association Française de Normalisation (AFNOR). (1982). Produits dérivés des fruits et légumes jus de fruits (pp. 328). Paris. France.

2. Association Française de Normalisation (AFNOR). (2011). Colorimétrie - Partie 4 : espace chromatique L*a*b* CIE $1976\left(1^{\mathrm{re}}\right.$ éd.) (pp. 8). Paris. France. 
3. Association Française de Normalisation (AFNOR). (2013). Microbiologie des aliments - Méthode horizontale pour le dénombrement des micro-organismes (1ère) (pp. 8). Paris. France.

4. Cisse O. I. K., Ayessou. N. C., Faye P. G., Cisse M., Camara. A. C., Bodian A., Ndiaye C., Sakho M. \& Diop C. M. (2018). Process Diagnosis and Aging Effects on a Traditional Millet-Based Drink: Boumkaye. Food and Nutrition Sciences, 09 (05): 464-473.

5. Dahouenon-Ahoussi E., Degnon R. G., Adjou E. S. \& Sohounhloue D. C. (2012). Stabilisation de la bière produite à partir de matières amylacées locales (Sorghum bicolor et Musa acuminata) par adjonction de l'huile essentielle de Cymbopogon citratus. J. Appl. Biosci., 51: 3596-3607.

6. Dewanto V., Wu X., Adom K. K. \& Liu, R. H. (2002). Thermal processing enhances the nutritional value of tomatoes by increasing total antioxidant activity. Journal of Agricultural and Food Chemistry, 50(10): 3010-3014.

7. Dicko M. H., Gruppen H., Traoré A. S., Voragen A. G. J. \& Van Berkel W. J. H. (2006). Sorghum grain as human food in Africa: relevance of content of starch and amylase activities. Afri. J. Biotechnol., 5: 384395.

8. Georgé S., Brat P., Alter P. \& Amiot M. J. (2005). Rapid Determination of Polyphenols and Vitamin C in Plant-Derived Products. Journal of Agricultural and Food Chemistry, 53(5): 13701373.

9. Kayodé A., Aégbid. A., Linnemenn A. R., Nout M. J. R. \& Hounhouigana J. D. (2005). Quality of farmer's varieties of sorghum and derived foods as perceived by consumers in Benin. Ecol. Food Nutr., 44: 271-294.

10. Kayodé A. P. P., Hounhouigan J. D. \& Nout M. J. R. (2007). Impact of brewing process operations on phytate, phenolic compounds and in vitro solubility of iron and zinc in opaque sorghum beer. LWT - Food Science and Technology, 40(5): 834-841.

11. Lyumugabe F., Gros J., Nzungize J., Bajyana E. \& Thonart P. (2012). Characteristics of African traditional beers brewed with sorghum malt - a review. Biotechnologie. Agronomie. Société et Environnement. 16 (4). 509-530.

12. Lyumugabe L., Kamaliza G., Bajyana E. \& Thonart P. (2010). Microbiological and physico-chemical characteristic of Rwandese traditional beer "Ikigage". Afr. J. Biotechnol., 9: 4241-4246.

13. Maoura N., Mbaiguinam M., Nguyen H., Gaillardin C. \& Pourquie J. (2005). Identification and typing of the yeast strains isolated from bili bili. a traditional sorghum beer of chad. Afr. J. Biotechnol., 4: 646-656. 
14. Monjerezi M., Vogt R. D., Aagaard P. \& Saka J. D. K. (2011). Hydrogeochemical processes in an area with saline groundwater in lower Shire River valley. Malawi: An integrated application of hierarchical cluster and principal component analyses. Applied Geochemistry, 26(8): 1399-1413.

15. Mwesigye P. K. \& Okurut T. O. (1995). A Survey of the Production and Consumption of Traditional Alcoholic Beverages in Uganda. Process Biochemestry, 30(6): 497-501.

16. Quin P. J. (1959). Foods and Feeding Habits of the Pedi (Witwatersrand University Press) (pp. 278). Johannesburg. South Africa.

17. Randhir R., Kwon Y. I. \& Shetty K. (2008). Effect of thermal processing on phenolics, antioxidant activity and health - relevant functionality of select grain sprouts and seedlings. Innovative Food Science \& Emerging Technologies, 9: 355-364.

18. Ranilla L. G., Genovese M. I. \& Lajolo F. M. (2009). Effect of different cooking conditions on phenolic compounds and antioxidant capacity of some selected Brazilian bean (Phaseolus vulgaris L.) cultivars. Journal of Agricultural and Food Chemistry, 57(13): 5734-5742.

19. Aucamp M. C., Grieff J. T., Novellie L., Papendick B., Schwartz H. M. \& Steer A. G. (1956). Kaffircorn malting and brewing studies. II.Studies on the microbiology of Kaffir beer. Journal of the Science of Food and Agriculture, 7(2): 105-113. 